\title{
Thermostabilization of the uronate dehydrogenase from Agrobacterium tumefaciens by semi-rational design
}

Teresa Roth ${ }^{1,2}$, Barbara Beer ${ }^{1}$, André Pick ${ }^{1}$ and Volker Sieber ${ }^{1,3,4^{*}}$ (D)

\begin{abstract}
Aldaric acids represent biobased 'top value-added chemicals' that have the potential to substitute petroleum-derived chemicals. Until today they are mostly produced from corresponding aldoses using strong chemical oxidizing agents. An environmentally friendly and more selective process could be achieved by using natural resources such as seaweed or pectin as raw material. These contain large amounts of uronic acids as major constituents such as glucuronic acid and galacturonic acid which can be converted into the corresponding aldaric acids via an enzyme-based oxidation using uronate dehydrogenase (Udh). The $U d h$ from Agrobacterium tumefaciens (UdhAt) features the highest catalytic efficiency of all characterized Udhs using glucuronic acid as substrate $\left(829 \mathrm{~s}^{-1} \mathrm{mM}^{-1}\right)$. Unfortunately, it suffers from poor thermostability. To overcome this limitation, we created more thermostable variants using semi-rational design. The amino acids for substitution were chosen according to the $\mathrm{B}$ factor in combination with four additional knowledge-based criteria. The triple variant A41P/H101Y/H236K showed higher kinetic and thermodynamic stability with a $T_{50}^{15}$ value of $62.2^{\circ} \mathrm{C}\left(3.2^{\circ} \mathrm{C}\right.$ improvement $)$ and a $\Delta \Delta G_{U}$ of $2.3 \mathrm{~kJ} / \mathrm{mol}$ compared to wild type. Interestingly, it was only obtained when including a neutral mutation in the combination.
\end{abstract}

Keywords: Uronate dehydrogenase, Glucuronic acid, Agrobacterium tumefaciens, Thermostability, B factor, Neutral drift

\section{Introduction}

The biocatalytic conversion of sugars from biomassderived waste offers a promising route for the biotechnological production of fuels, chemicals and materials (Andberg et al. 2012). Next to sugars also sugar derivatives constitute an important building block of natural fibers and are therefore readily available.

Glucaric and other aldaric acids are considered topvalue added chemicals to be obtained from biomass and have the potential for various applications such as a building block for polymers and hyperbranched polyesters (Werpy and Petersen 2004). Currently glucaric acid is produced from glucose using strong oxidants like nitric acid (Werpy and Petersen 2004). This process is expensive and

\footnotetext{
*Correspondence: sieber@tum.de

${ }^{1}$ Chair of Chemistry of Biogenic Resources, Straubing Centre of Science, Technical University of Munich, Schulgasse 16, 94315 Straubing, Germany Full list of author information is available at the end of the article
}

not selective. Higher selectivity could be achieved with an enzyme-based system for the production of glucaric acid. Moon et al. (2009) already constructed an enzyme-based pathway for the conversion of glucose to glucaric acid. The three enzymes myo-inositol-1-phosphate synthase, myo-inositol oxygenase and uronate dehydrogenase were recombinantly expressed in $E$. coli. However, only a yield of $17.4 \%(0.72 \mathrm{~g} / \mathrm{l})$ was achieved due to competition with the endogenous metabolism, which may limit carbon flux into the pathway for glucaric acid production. By inhibiting this flux through knockdown of phosphofructokinase an improvement up to a yield of $42 \%(1.56 \mathrm{~g} / \mathrm{l})$ could be achieved (Reizman et al. 2015). Due to the use of multiple enzymes this enzyme-based production of glucaric acid is still complex and insufficient. Instead of using glucose as the basic raw material the two ubiquitous sugar derivatives glucuronic acid and galacturonic acid would be more suitable to gain aldaric acids. Glucuronic acid is a component 
of hemicellulose, hyaluronic acid and seaweed, whereas the plant polysaccharide pectin largely consists of galacturonic acid (Ahn et al. 2012; Andberg et al. 2012). They can be oxidized to the corresponding aldaric acids by the enzyme uronate dehydrogenase (Udh, EC 1.1.1.203). For this conversion only the enzyme Udh would be required to obtain an enzyme-based system. The cell-based production of glucaric acid by Moon et al. (2009) is further limited by the intracellular accumulation of the product and the resulting acidification. This problem could be avoided by using a cell-free biosystem. A cell-free production has further advantages, i.e. easy control of the process, no substrate or product toxicity, higher product titer and broad reaction conditions (Guterl et al. 2012; You and Zhang 2012). Moreover the necessary cofactor nicotinamide adenine dinucleotide could easily be recycled to allow process operation under economic conditions. The recently characterized NADH oxidase from Lactobacillus pentosus which only forms water as byproduct would be a suitable enzyme in this process (Nowak et al. 2015).

The oxidation of uronic acids to aldaric acids by Udh was first described in the phythopathogenic bacteria Pseudomonas syringae and Agrobacterium tumefaciens (Zajic 1959). Until now several Udhs of the following organisms have been characterized: Agrobacterium tumefaciens, Fulvimarina pelagi, Oceanicola granulosus, Streptomyces viridochromogenes, Pseudomonas syringae, Pseudomonas putida, Pseudomonas mendocina, Pseudomonas fluorescens, Polaromonas naphthalenivorans and Chromohalobacter salixigens (Boer et al. 2010; Pick et al. 2015; Yoon et al. 2009; Wagschal et al. 2014). The best characterized enzyme is the Udh from Agrobacterium tumefaciens (UdhAt), which belongs to the short-chain dehydrogenase/reductase (SDR) superfamily and accepts only $\mathrm{NAD}^{+}$as cofactor (Pick et al. 2015). The enzyme forms a hexamer in which two monomers interact tightly through the contact of the $\alpha$-helices 3 and 4 (PDB code: 3RFT). Three dimers are then more loosely packed to form the hexamer. Each monomer consists of a single domain with the typical Rossmann fold for cofactor binding (Parkkinen et al. 2011; Pick et al. 2015). In comparison to the other Udhs the one derived from Agrobacterium tumefaciens features the highest catalytic efficiency $\left(829 \mathrm{~s}^{-1} \mathrm{mM}^{-1}\right)$ using glucuronic acid as substrate. Nevertheless, its short half-life of only $50 \mathrm{~min}$ at $37{ }^{\circ} \mathrm{C}$ is limiting its potential for industrial applications (Pick et al. 2015). Therefore the aim of this study was to overcome this limitation by improving the thermostability using enzyme engineering.

We chose a semi-rational design due to the availability of the crystal structure of the UdhAt. This helped to define positions for substitution, which could lead to a greater thermostability without losing or diminishing enzyme activity.
Systematic structural studies regarding mesophilic and thermophilic enzymes have shown that the latter are characterized by higher degrees of rigidity. This can be achieved by the accumulation of a variety of effects like hydrogen bonds or salt bridges. So, increasing the rigidity of the enzyme at appropriate sites should enhance thermostability (Reetz and Carballeira 2006). Therefore, the first and leading criterion was the B factor (atomic displacement parameter), which describes the movement of an atom around its mean position and therefore shows the flexibility and dynamics of the protein structure (Parthasarathy and Murthy 2000). The factor is determined for each atom in a protein structure during high-resolution X-ray crystallography. The average B factor for an amino acid position is then calculated by the program B-FITTER (Carballeira and Reetz 2007). Apart from this tool, informations on appropriate sites for mutagenesis can also be obtained from empirical studies that determine how amino acid side chains affect secondary or tertiary structures (Spector et al. 2000; Sriprapundh et al. 2000) or from looking at amino acid conservation (Anbar et al. 2012; Wijma et al. 2013). This rational approach for the selection of amino acids for mutagenesis is then combined with randomization using degenerated primers to find the best amino acid substitution at the specified positions. The generated smart enzyme libraries are small and can such easily be screened in a short period of time to find variants with improved thermostability.

\section{Materials and methods Reagents}

All chemicals were of analytical grade or higher quality and purchased from Sigma-Aldrich, Molekula, Carl Roth, Alfa Aesar and VWR. For protein purification, equipment and columns, from GE Healthcare were used (Munich, Germany).

\section{Strains and plasmid}

The strains E. coli XL1 BLUE and E. coli BL21(DE3) were used during this work. Construction of the plasmid pCBR-udh-A.t. was described by Pick et al. (2015).

\section{Enzyme expression and purification}

Escherichia coli BL21(DE3) containing the plasmid of interest was grown in $250 \mathrm{ml}$ autoinduction medium (Studier 2005). The preculture was incubated in $20 \mathrm{ml}$ of $\mathrm{LB}$ medium with $30 \mu \mathrm{g} / \mathrm{ml}$ kanamycin at $37^{\circ} \mathrm{C}$ overnight on a rotary shaker $(180 \mathrm{rpm})$. The expression culture was then inoculated to reach an $\mathrm{OD}_{600 \mathrm{~nm}}$ of 0.1 . Incubation was performed for $4 \mathrm{~h}$ at $37^{\circ} \mathrm{C}$ followed by incubation for $21 \mathrm{~h}$ at $16{ }^{\circ} \mathrm{C}$. Cells were harvested by centrifugation and resuspended in $50 \mathrm{mM}$ potassium phosphate buffer (KPi) pH $8.0(10 \mathrm{mM}$ imidazol, $500 \mathrm{mM} \mathrm{NaCl}$ and $10 \%$ 
glycerol). Crude extracts were prepared with a Basic-Z Cell Disrupter (IUL Constant Systems) and subsequent incubation with $\mathrm{MgCl}_{2}(2.5 \mathrm{mM})$ and DNaseI $(1 \mu \mathrm{g} / \mathrm{ml})$ for $20 \mathrm{~min}$ at room temperature to degrade DNA. The insoluble fraction of the lysate was removed by centrifugation $\left(20,000 \mathrm{rpm}\right.$ for $40 \mathrm{~min}$ at $\left.4{ }^{\circ} \mathrm{C}\right)$. The supernatant was applied to an IMAC affinity column, $5 \mathrm{ml} \mathrm{HisTrap}^{\text {TM }}$ $\mathrm{FF}$, equilibrated with the resuspension buffer using the ÄKTA Purifier-system. The column was washed with $20 \mathrm{ml}$ of resuspension buffer and the enzyme was eluted with $50 \mathrm{mM}$ KPi buffer pH 8.0 (500 mM imidazol, $500 \mathrm{mM} \mathrm{NaCl}$ and $10 \%$ glycerol). Elution was monitored by UV $(280 \mathrm{~nm})$ and fractions containing protein were subjected to $12 \%$ SDS-Page described by Laemmli (1970). The molecular weight of UdhAt was calculated to be $31.21 \mathrm{kDa}$ (including the additional amino acids of the $\mathrm{N}$-terminal $\mathrm{His}_{6}$-tag) using the ProtParam tool (Expasy). Factions containing the eluted target protein were pooled and desalted using a HiPrep ${ }^{\mathrm{TM}}$ 26/10 Desalting column which was preliminary equilibrated with $50 \mathrm{mM}$ ammonium bicarbonate $\mathrm{pH}$ 7.9. Protein concentrations were determined using a NanoPhotometer (IMPLEN) with $50 \mathrm{mM}$ ammonium bicarbonate $\mathrm{pH} 7.9$ as the reference and an extinction coefficient of $37,930 \mathrm{M}^{-1} \mathrm{~cm}^{-1}$ (ProtParam, Expasy).

\section{Enzyme assay}

The Udh activity was determined photometrically by monitoring the increase of NADH at $340 \mathrm{~nm}$ with a Multiskan spectrum spectrophotometer (Thermo Fisher Scientific). The reaction mixture contained $25 \mathrm{mM} \mathrm{KPi}$ buffer $\mathrm{pH}$ 8.0, $1 \mathrm{mM} \mathrm{NAD}{ }^{+}, 5 \mathrm{mM} \mathrm{MgCl}_{2}$ and $10 \mathrm{mM}$ glucuronic acid. Measurements were performed at $25^{\circ} \mathrm{C}$ after adding $20 \mu \mathrm{l}$ of purified enzyme $\left(9.1 \times 10^{-5} \mathrm{mg} / \mathrm{ml}\right)$. One unit of enzyme activity was defined as the amount of protein that oxidizes $1 \mu \mathrm{mol}$ of $\mathrm{NADH} / \mathrm{min}$ at $25^{\circ} \mathrm{C}$.

\section{Mutagenesis}

Saturation mutagenesis libraries were generated using the QuikChange ${ }^{\circledR}$ mutagenesis strategy from Stratagene (USA). The degenerated primers used (Table 1) contained the codon NNK. High quality of the generated libraries was verified by sequencing five clones per library (GATC Biotech, Cologne, Germany).

\section{Culture conditions for 96 deep-well plates}

Escherichia coli BL21(DE3) containing the plasmid (plasmid libraries) of interest were used for expression in 96 well format. The colonies were picked using the Hudson Rapid Pick lite colony picker (Hudson Robotics Inc., Springfield, USA) and grown in 96 deep-well plates containing $1200 \mu \mathrm{l}$ autoinduction medium (Studier 2005)
Table 1 Primers used for saturation mutagenesis

\begin{tabular}{|c|c|}
\hline & Sequence $5^{\prime}-3^{\prime}$ \\
\hline L38fw & GATCTGTCTCCGNNKGATCCGGCTGGTCCGAATGAAG \\
\hline L38rv & CAGCCGGATCMNNCGGAGACAGATCTGCCAGAC \\
\hline A41fw & CCGCTGGATCCGNNKGGTCCGAATGAAGAATGTGTTC \\
\hline A41rv & CTTCATTCGGACCMNNCGGATCCAGCGGAGACAGATC \\
\hline E81fw & $\begin{array}{l}\text { GCGTTGAAAAACCGTTTNNKCAGATTCTGCAGGGTAACAT- } \\
\text { TATTGGC }\end{array}$ \\
\hline E81rv & CCCTGCAGAATCTGMNNAAACGGTTTTTCAACGCTAATGCCAC \\
\hline H101fw & GCAGCACGTGCANNKGGTCAGCCTCGTATTGTTTTTGCAAG \\
\hline H101rv & CAATACGAGGCTGACCMNNTGCACGTGCTGCTTCATACAG \\
\hline H236fw & GCCTTTCGTCGTNNKATTACCGAAACCACACCGCCTCCG \\
\hline H236rv & $\begin{array}{l}\text { GGTGTGGTTTCGGTAATMNNACGACGAAAGGCTTCTGCAT- } \\
\text { TATCTTTCGG }\end{array}$ \\
\hline E239fw & GTCGTCATATTACCNNKACCACACCGCCTCCGGATCCGAATG \\
\hline E239rv & CCGGAGGCGGTGTGGTMNNGGTAATATGACGACGAAAGGCTTC \\
\hline
\end{tabular}

with $100 \mu \mathrm{g} / \mathrm{ml}$ kanamycin, for $25 \mathrm{~h}$ at $37^{\circ} \mathrm{C}$ on a rotary shaker $(1000 \mathrm{rpm}) .100 \mu \mathrm{l}$ of the cultures were centrifuged (3000 rpm for $15 \mathrm{~min}$ at $4{ }^{\circ} \mathrm{C}$ ), the supernatants discarded and the cell pellets frozen at $-80{ }^{\circ} \mathrm{C}$ for at least $2 \mathrm{~h}$. Afterwards $100 \mu \mathrm{l}$ of $25 \mathrm{mM} \mathrm{KPi} \mathrm{pH} 8.0$ were added and the plates incubated for $1 \mathrm{~h}$ at $37{ }^{\circ} \mathrm{C}$ on a rotary shaker $(700 \mathrm{rpm})$ for cell disruption.

\section{Screening}

The screening for thermostability was assessed based on the residual activity subsequent to the exposure to high temperatures. The supernatants were diluted (1:2000 in a total volume of $50 \mu \mathrm{l}$ ) in incubation mixture containing $25 \mathrm{mM} \mathrm{KPi} \mathrm{pH} \mathrm{8.0,} 5 \mathrm{mM} \mathrm{MgCl}_{2}$ and $100 \mathrm{mM}$ glucuronic acid. Before incubation the initial activity was measured using an aliquot of $20 \mu \mathrm{l}$ and adding $180 \mu \mathrm{l}$ of reaction mixture $\left(25 \mathrm{mM} \mathrm{KPi} \mathrm{pH} 8.0\right.$ and $\left.1 \mathrm{mM} \mathrm{NAD}^{+}\right)$. Heat treatment was performed for $15 \mathrm{~min}$ at $58{ }^{\circ} \mathrm{C}$ in a PCR thermocycler. After cooling to $4{ }^{\circ} \mathrm{C}$ another aliquot of $20 \mu \mathrm{l}$ was used to measure the residual activity. Variants showing a residual activity greater than the wildtype enzyme plus standard deviation were considered as hits.

\section{Kinetic stability}

Kinetic stability can be described by $\mathrm{T}_{50}^{15}$, the temperature at which $50 \%$ of the enzyme's initial activity is left after incubation for a defined time period. For this purpose, a gradient PCR thermocycler was used. The purified enzymes were incubated at $50-64{ }^{\circ} \mathrm{C}$ at the same enzyme concentration $\left(9.1 \times 10^{-5} \mathrm{mg} / \mathrm{ml}\right)$ with $25 \mathrm{mM}$ $\mathrm{KPi} \mathrm{pH} \mathrm{8.0,} 5 \mathrm{mM} \mathrm{MgCl}, 0.1 \mathrm{mg} / \mathrm{ml} \mathrm{BSA}$ and $100 \mathrm{mM}$ glucuronic acid. 


\section{Thermodynamic stability}

The thermodynamic stability was determined by guanidine hydrochloride ( $\mathrm{GdmCl})$ induced unfolding. Therefore, $100 \mu \mathrm{l}$ protein were incubated with various concentrations of $\mathrm{GdmCl}(0-3.5 \mathrm{M})$ in $25 \mathrm{mM} \mathrm{KPi}$ $\mathrm{pH} 8.0$ for 8 days at RT. The proteins were transferred into a 96-well optical-bottom plate (Thermo Fisher Scientific) and the fluorescence emission at $344 \mathrm{~nm}$ was measured after excitation at $278 \mathrm{~nm}$ in a Varioskan (Thermo Fisher Scientific). The difference in free energy of unfolding of WT and the variants $\left(\Delta \Delta G_{U}\right)$ was calculated using the following equation: $\Delta \Delta G_{U}=0.5\left(m_{\text {wild type }}+m_{\text {variant }}\right) \Delta[G d m C l]_{50 \%}$, where $\mathrm{m}$ is the slope of the linear denaturation plot $-\mathrm{dAGu} /$ $\mathrm{d}[$ denaturant $]$ and $\Delta[\mathrm{GdmCl}]_{50 \%}$ is the difference between $[\mathrm{GdmCl}]_{50 \%}$ for wild type and mutant (Kellis et al. 1989).

\section{Determination of kinetic parameters}

Kinetic parameters $\left(\mathrm{k}_{\mathrm{cat}}\right.$ and $\left.\mathrm{K}_{\mathrm{M}}\right)$ were determined for WT and purified variants. Measurements were performed in $25 \mathrm{mM} \mathrm{KPi} \mathrm{pH} 8.0$ at $25{ }^{\circ} \mathrm{C}$ with varying concentrations of glucuronate $\left(0-10,1 \mathrm{mM} \mathrm{NAD}{ }^{+}\right)$or $\mathrm{NAD}^{+}(0-4,10 \mathrm{mM}$ glucuronate). The increase of NADH was monitored at $340 \mathrm{~nm}$ with a Multiskan spectrum spectrophotometer (Thermo Fisher Scientific). The data was fitted to the Michaelis-Menten equation using SigmaPlot 11.0.

\section{Results}

\section{Identification of amino acid positions for mutagenesis}

Site-saturation mutagenesis has proven to be a useful strategy to alter enzyme properties like thermal stability or substrate specificity when the amino acid positions are properly selected (Reetz and Carballeira 2006). Setting the B factor as a criterion was already suggested by Parthasarathy and Murthy (2000) and further successfully applied for thermal stabilization of Bacillus subtilis lipase (Reetz and Carballeira 2006) and an $\alpha$-Amino ester hydrolase (Blum et al. 2012). Hence, we used the $B$ factor as our leading criterion. In multiple studies the
B factor was combined with the structure-guided consensus method to reduce the number of amino acids to be mutated (Blum et al. 2012; Jochens et al. 2010). In our case a combination of those methods was not suitable because the consensus sequence of all known Udhs (using the recommended cut off of 80\%) was identical to the sequence of the UdhAt. Therefore, we chose four other criteria in combination with a $B$ factor greater than $25 \AA^{2}$ : first, the localization of amino acids within the protein was considered. Amino acids within elements of pronounced secondary structure were excluded for mutagenesis except when they have a low propensity for this type of secondary structure (Bommarius and Paye 2013; Lehmann and Wyss 2001). In addition amino acids that are within the cofactor and substrate binding sites or at the interface between the protein domains of the multimer ( $\alpha$-helices 3 and 4) were not considered. Second, amino acids that occur more often in proteins from thermophilic origin and are typically considered for protein stabilization such as proline, arginine and tyrosine were excluded from mutagenesis (Querol et al. 1996; Lehmann and Wyss 2001). Furthermore, conserved amino acids as well as amino acids that are probably involved in a hydrogen bonding network (PyMOL) were excluded. Conserved amino acids are advantageous for the protein and "survived" during evolution (survival of the fittest) (Bommarius and Paye 2013). Therefore, sequence and structure alignments of all known Udhs and enzymes that had a sequence similarity greater than $60 \%$ compared to the UdhAt were created. From these alignments consensus sequences with coverage of 95 or $80 \%$ were created (BioEdit and PROMALS) and all amino acids that showed conservation were excluded from mutagenesis. An overview of these five criteria and the amino acids considered for mutagenesis is shown in Table 2. Six amino acids fulfilled all five criteria: L38, A41, E81, H101, H236 and E239. They were subjected to site-directed mutagenesis via QuikChange PCR using degenerated primers with an NNK motif, covering at least one codon of all canonical amino acids.

Table 2 The five criteria for selecting the amino acid positions for mutagenesis

\begin{tabular}{ll}
\hline Criterion & Amino acids \\
\hline B factor $>25$ A $^{2}$ & K4, Q14, R17, E21, A24, P25, M26, E28, S36, P37, L38, D39, P40, A41, G42, P43, N44, E45, E46, Q49, A63, P79, E81, \\
& $\begin{array}{l}\text { H101, G134, F154, C166, T167, P168, E169, N171, F180, S181, E190, H218, G223, K227, R235, H236, T238, E239, } \\
\text { T240, T241, P242, P243, P244 }\end{array}$ \\
Location & $\begin{array}{l}\text { K4, M26, P37, L38, D39, P40, A41, G42, P43, N44, E45, A63, P79, E81, H101, T167, P168, E169, N171, F180, E190, } \\
\text { K227, H236, T238, E239, P242, P243, P244 }\end{array}$ \\
Occurrence in thermostable proteins & K4, M26, L38, D39, A41, G42, N44, E45, A63, E81, H101, T167, E169, N171, F180, E190, K227, H236, T238, E239 \\
Conservation & M26, L38, D39, A41, G42, N44, A63, E81, H101, E169, N171, F180, E190, K227, H236, T238, E239 \\
Part of hydrogen bonding network & L38, A41, E81, H101, H236, E239 \\
\hline
\end{tabular}




\section{Screening of mutant libraries}

The stability of proteins can be judged by three types of criteria: kinetic, thermodynamic and process stability (Bommarius and Paye 2013).

Fast screening to examine improved thermostability in the initial six libraries was performed in 96-well PCR plates by heating the enzyme solutions (diluted supernatants) to $58^{\circ} \mathrm{C}$ for $15 \mathrm{~min}$ in a thermocycler. The temperature of $58{ }^{\circ} \mathrm{C}$ was chosen because it reduced WT activity to $10 \%$ (standard deviation of $2 \%$ ) allowing a fast identification of positive hits. In library H236 three variants showed a higher stability: H236K, H236I and H236R. All other enzyme variants in all other libraries showed lower thermostability than WT with exception of the variants A41P, H101Y and $\mathrm{H} 101 \mathrm{~N}$, which were as stable as wild type enzyme. With only one position giving rise to improvements no combination of improved variants for possible additive or even synergistic effects was possible. However, recently several interesting studies had shown the importance of neutral drift on the evolution of enzymes (Gupta and Tawfik 2008; Smith et al. 2011). This led us to combine the mutations that were positive in the screen with the ones that at least did not show any decrease in activity. We created a series of double and triple variants in addition to the single variants $\mathrm{H} 236 \mathrm{~K}$, H236I and H236R (see Table 3).

Again, the residual activity after incubation at $58{ }^{\circ} \mathrm{C}$ was measured (data not shown). Only the double variant $\mathrm{A} 41 \mathrm{P} / \mathrm{H} 236 \mathrm{R}$ showed a reduced thermostability in the screen. The remaining 17 variants were purified and their kinetic and thermodynamic stability was compared as well as their kinetic parameters determined.

\section{Kinetic stability}

The $\mathrm{T}_{50}^{15}$ value was defined as the temperature required to reduce the initial enzyme activity to $50 \%$ within $15 \mathrm{~min}$. The $\mathrm{T}_{50}^{15}$ of the purified WT enzyme was $59.0{ }^{\circ} \mathrm{C}$. In Fig. 1 the $\mathrm{T}_{50}^{15}$ of WT and variants are shown. All variants had an improved or equal kinetic stability compared to WT. The highest improvement of kinetic stability was observed for the triple variant $\mathrm{A} 41 \mathrm{P} / \mathrm{H} 101 \mathrm{Y} / \mathrm{H} 236 \mathrm{~K}$ with a $\mathrm{T}_{50}^{15}$ value of $62.2^{\circ} \mathrm{C}$, resulting in a $\Delta \mathrm{T}_{50}^{15}$ of $3.2^{\circ} \mathrm{C}$ compared to WT.

\section{Thermodynamic stability}

The thermodynamic stability was determined by GdmClinduced protein unfolding. The differences in free energy of unfolding of the single and triple variants compared to WT $\left(\Delta \Delta \mathrm{G}_{\mathrm{U}}\right)$ are shown in Fig. 2. The single variants all showed negative $\Delta \Delta \mathrm{GU}$ compared to the wildtype, except H236K and H236I. However, the $\Delta \Delta \mathrm{GU}$ of all double and triple variants - with exception of A41P/ H101Y/H236R-were positive, which indicates that these variants have a higher thermodynamic stability than WT. Moreover, this stabilization is non-additive, as the single variants that were neutral in the screening, showed even lower stability than the WT when tested in the purified form. The best variant was the triple variant A41P/ $\mathrm{H} 101 \mathrm{Y} / \mathrm{H} 236 \mathrm{~K}$ with a $\Delta \Delta \mathrm{G}_{\mathrm{U}}$ of $2.3 \mathrm{~kJ} / \mathrm{mol}$. In Fig. 3 the unfolding curves of WT, the single variant $\mathrm{H} 236 \mathrm{~K}$ and the best variant A41P/H101Y/H236K are shown.

\section{Kinetic parameters}

The kinetic parameters $\mathrm{v}_{\max }, \mathrm{K}_{\mathrm{m}}$ and $\mathrm{k}_{\text {cat }} / \mathrm{K}_{\mathrm{m}}$ for the substrate glucuronic acid and the cofactor $\mathrm{NAD}^{+}$were determined for the eight best variants. WT had a specific activity of $390 \mathrm{U} / \mathrm{mg}$, a $\mathrm{K}_{\mathrm{m}}$ of $0.71 \mathrm{mM}$ and a catalytic efficiency of $287 \mathrm{~s}^{-1} \mathrm{mM}^{-1}$. In comparison, the variants had a slightly reduced specific activity and a higher $\mathrm{K}_{\mathrm{m}}$ value (Table 4) resulting also in a reduced catalytic efficiency (40-60\% compared to WT).

\section{Discussion}

With the enzyme uronate dehydrogenase a selective one-step enzyme-based production of aldaric acids from waste biomass could be possible. The uronate dehydrogenase from Agrobacterium tumefaciens (UdhAt) features the highest efficiency among all known Udhs using glucuronic acid as substrate. However, the enzyme lacks stability with only a half-life of $50 \mathrm{~min}$ at $37{ }^{\circ} \mathrm{C}$ (Pick et al. 2015). This limits its potential for industrial application. As no Udh is known from thermophilic organisms, we developed more thermostable variants by enzyme engineering.

This was achieved through the combination of an effective selection method for the amino acid positions to be mutated and the accumulation of advantageous mutations.

Table 3 Created single, double and triple variants of UdhAt to test for additive or synergistic effects

\begin{tabular}{|c|c|c|c|c|c|}
\hline \multirow[t]{2}{*}{ Single variants } & \multicolumn{3}{|c|}{ Double variants, combining single variants and: } & \multicolumn{2}{|c|}{ Triple variants, combining single variants and: } \\
\hline & A41P & H101Y & $\mathrm{H} 101 \mathrm{~N}$ & A41P/H101Y & $\mathrm{A} 41 \mathrm{P} / \mathrm{H} 101 \mathrm{~N}$ \\
\hline H236K & $\mathrm{A} 41 \mathrm{P} / \mathrm{H} 236 \mathrm{~K}$ & $\mathrm{H} 101 \mathrm{Y} / \mathrm{H} 236 \mathrm{~K}$ & $\mathrm{H} 101 \mathrm{~N} / \mathrm{H} 236 \mathrm{~K}$ & $\mathrm{~A} 41 \mathrm{P} / \mathrm{H} 101 \mathrm{Y} / \mathrm{H} 236 \mathrm{~K}$ & $\mathrm{~A} 41 \mathrm{P} / \mathrm{H} 101 \mathrm{~N} / \mathrm{H} 236 \mathrm{~K}$ \\
\hline $\mathrm{H} 236 \mathrm{l}$ & A41P/H236l & H101Y/H236l & $\mathrm{H} 101 \mathrm{~N} / \mathrm{H} 236 \mathrm{l}$ & A41P/H101Y/H236l & A41P/H101N/H236l \\
\hline H236R & A41P/H236R & $\mathrm{H} 101 \mathrm{Y} / \mathrm{H} 236 \mathrm{R}$ & $\mathrm{H} 101 \mathrm{~N} / \mathrm{H} 236 \mathrm{R}$ & $\mathrm{A} 41 \mathrm{P} / \mathrm{H} 101 \mathrm{Y} / \mathrm{H} 236 \mathrm{R}$ & $\mathrm{A} 41 \mathrm{P} / \mathrm{H} 101 \mathrm{~N} / \mathrm{H} 236 \mathrm{R}$ \\
\hline
\end{tabular}




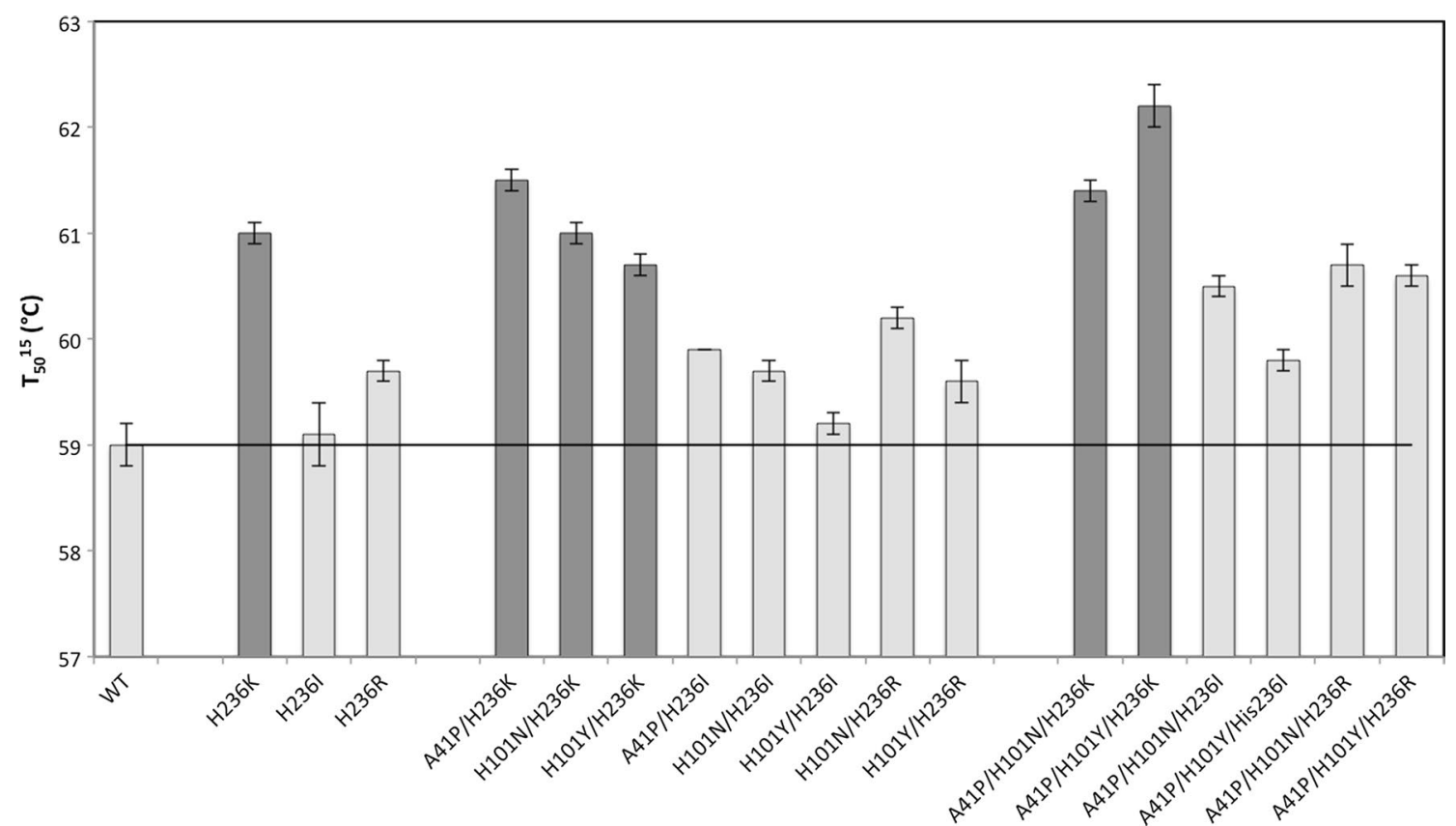

Fig. $1 T_{50}^{15}$ value of WT and 17 variants of UdhAt. Variants containing the mutation H236K are marked dark grey. The solid line indicates the $T_{50}^{15}$ value of WT $\left(59^{\circ} \mathrm{C}\right)$. Error bars are the standard deviation of four independent measurements

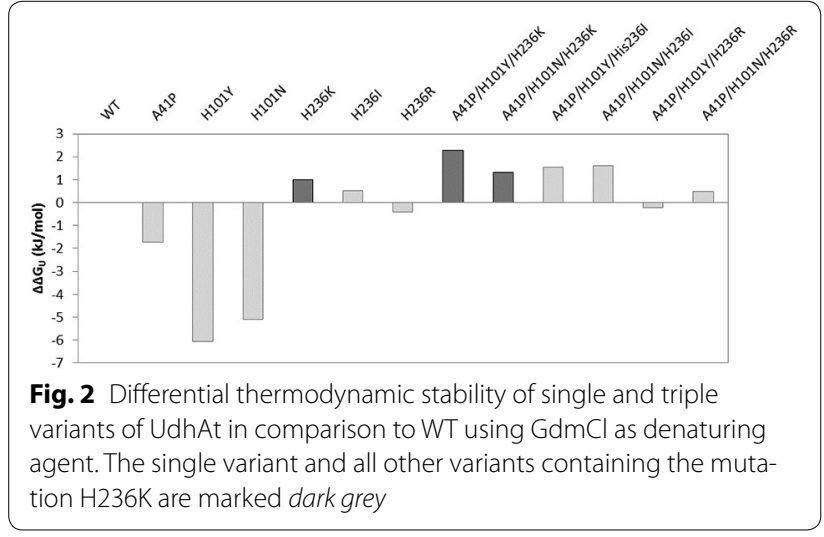

The selection method for the amino acids was based on the $B$ factor and four further criteria leading to the positions: L38, A41, E81, H101, H236 and E239. In the library H236 the three variants H236K, H236I and H236R had a greater thermostability than WT. The variants A41P, H101Y and H101N showed no change (positive or negative) and were therefore used to test for additivity. The triple variant $\mathrm{A} 41 \mathrm{P} / \mathrm{H} 101 \mathrm{Y} / \mathrm{H} 236 \mathrm{~K}$ showed the highest kinetic $\left(\Delta \mathrm{T}_{50}^{15}=3.2{ }^{\circ} \mathrm{C}\right)$ and thermodynamic stability $\left(\Delta \Delta \mathrm{G}_{\mathrm{U}}=2.3 \mathrm{~kJ} / \mathrm{mol}\right)$ compared to WT. When two or more point mutations are introduced, the question arises whether they interact additively or non-additively. In the latter case they can cause either cooperative (positive) or

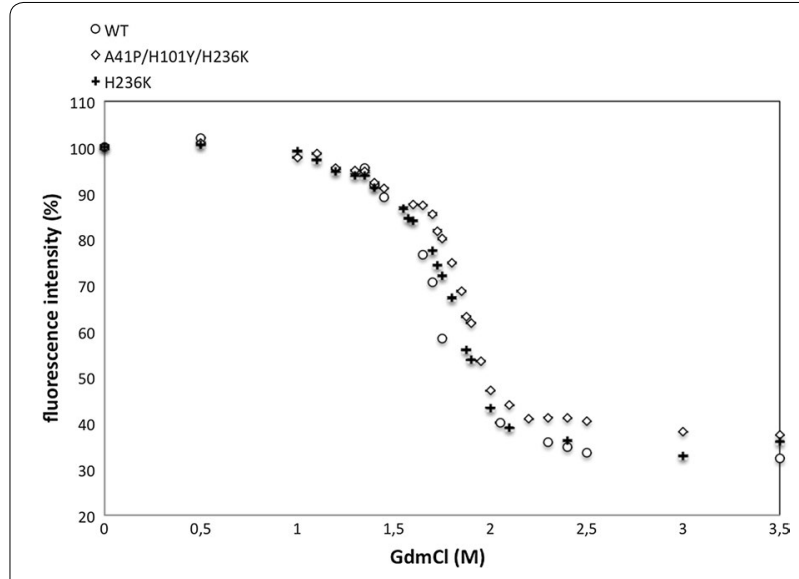

Fig. 3 Fluorescence intensity of WT, the best triple variant A41P/ $\mathrm{H} 101 \mathrm{Y} / \mathrm{H} 236 \mathrm{~K}$ and the single variant H236K. All data points are the mean value of twenty samples with a standard deviation of $<0.5$

antagonistic (negative) effects. It was suggested (Reetz 2013; Skinner and Terwilliger 1996) that additive effects might occur when the locations of mutations are well-separated. Whereas when the side chains of two residues are in close contact with one another their effects are generally non-additive. Our best variant A41P/H101Y/H236K showed non-additive synergistic cooperative effects, because the increase in thermostability was greater than the sum of the three single variants although the positions 
Table 4 Kinetic parameters of the eight best variants and WT for glucuronic acid including the standard deviation of three measurements

\begin{tabular}{llccc}
\hline Variant & $\begin{array}{l}\text { Specific } \\
\text { activity }(\mathbf{U} / \\
\mathbf{m g})\end{array}$ & $\mathbf{K}_{\mathbf{m}}(\mathbf{m M})$ & \multicolumn{2}{c}{ Catalytic efficiency } \\
\cline { 4 - 5 } & $391 \pm 17$ & $0.7 \pm 0.1$ & $286.4 \pm 13.0$ & 100 \\
\hline WT & $234 \pm 5$ & $1.3 \pm 0.1$ & $97.5 \pm 2.2$ & 34.0 \\
H236K & $407 \pm 8$ & $1.2 \pm 0.0$ & $179.5 \pm 3.5$ & 62.7 \\
A41P/H236K & $218 \pm 6$ & $1.0 \pm 0.1$ & $116.7 \pm 3.4$ & 40.8 \\
H101Y/H236K & $228 \pm 5$ & $0.9 \pm 0.1$ & $139.7 \pm 3.2$ & 48.8 \\
H101N/H236K & $280 \pm 6$ & $0.9 \pm 0.1$ & $167.3 \pm 3.6$ & 58.4 \\
A41P/H101Y/H236K & 20.1 & (\%) \\
A41P/H101Y/H236R & $302 \pm 4$ & $1.0 \pm 0.1$ & $160.5 \pm 2.0$ & 56.0 \\
A41P/H101N/H236K & $248 \pm 4$ & $0.9 \pm 0.1$ & $149.7 \pm 2.25$ & 52.3 \\
A41P/H101N/H236R & $330 \pm 3$ & $1.0 \pm 0.0$ & $170.0 \pm 1.7$ & 59.3 \\
\hline
\end{tabular}

are not in close proximity $\left(>20 \AA^{2}\right)$. Istomin et al. (2008) have obtained new insights concerning this topic. They concluded that a statistically significant bias toward nonadditivity occurs whenever the residues, although not in direct contact, are located within the same rigid cluster. Additivity can be expected when they are in different clusters. Also Reetz et al. (2009) could show that the hyperthermophilic mutant XI of the lipase from Bacillus subtilis had cooperative non-additive effects between five distal residues. The stabilization was performed by the formation of an extensive $\mathrm{H}$-bond/salt-bridge network on the surface of the enzyme. This could be the same case here because all three amino acid positions A41, H101 and H236 are located on the surface of the enzyme (Fig. 4). Furthermore, the substitution A41P helped to regain the catalytic function of the H236 mutation. The catalytic efficiency of the single variant $\mathrm{H} 236 \mathrm{~K}$ decreased to $34 \%$ of the wildtype activity, but was reconstituted to $63 \%$ in the double variant $\mathrm{A} 41 \mathrm{P} / \mathrm{H} 236 \mathrm{~K}$. The triple variant $\mathrm{A} 41 \mathrm{P} / \mathrm{H} 101 \mathrm{Y} / \mathrm{H} 236 \mathrm{~K}$ with the highest stability still showed $56 \%$ of the wildtype activity (Table 4). This finding nicely demonstrates the potential of neutral drift mutations that have gained interest in the last decade (Bershtein et al. 2008; Bloom and Arnold 2009; Smith et al. 2011).

The mutation $\mathrm{H} 236 \mathrm{~K}$ had the greatest influence on thermostability of the UdhAt. The amino acid histidine at the position 236 had a high B factor $\left(31.53 \AA^{2}\right)$ and was located in an $\alpha$-helix. Histidine is not a good helix builder whereas the introduced amino acid lysine is. Interestingly, when we applied the strategy of Blum et al. (2012), who showed that consensus sequences with a rather low cutoff could lead to thermally more stable enzyme variants, Lysine 236 was indeed conserved (at a cut-off of 30\%). In this consensus sequence 64 amino acids not identical to the UdhAt were conserved, i.e. E239A. Our screening assay did not find a preferable amino acid exchange at this position. At the positions A41, E81 and H101 wild type amino acid of UdhAt was conserved. This confirms the strategy of Blum et al. (2012) combining the B factor with the structure-guided consensus (SGC) concept: they

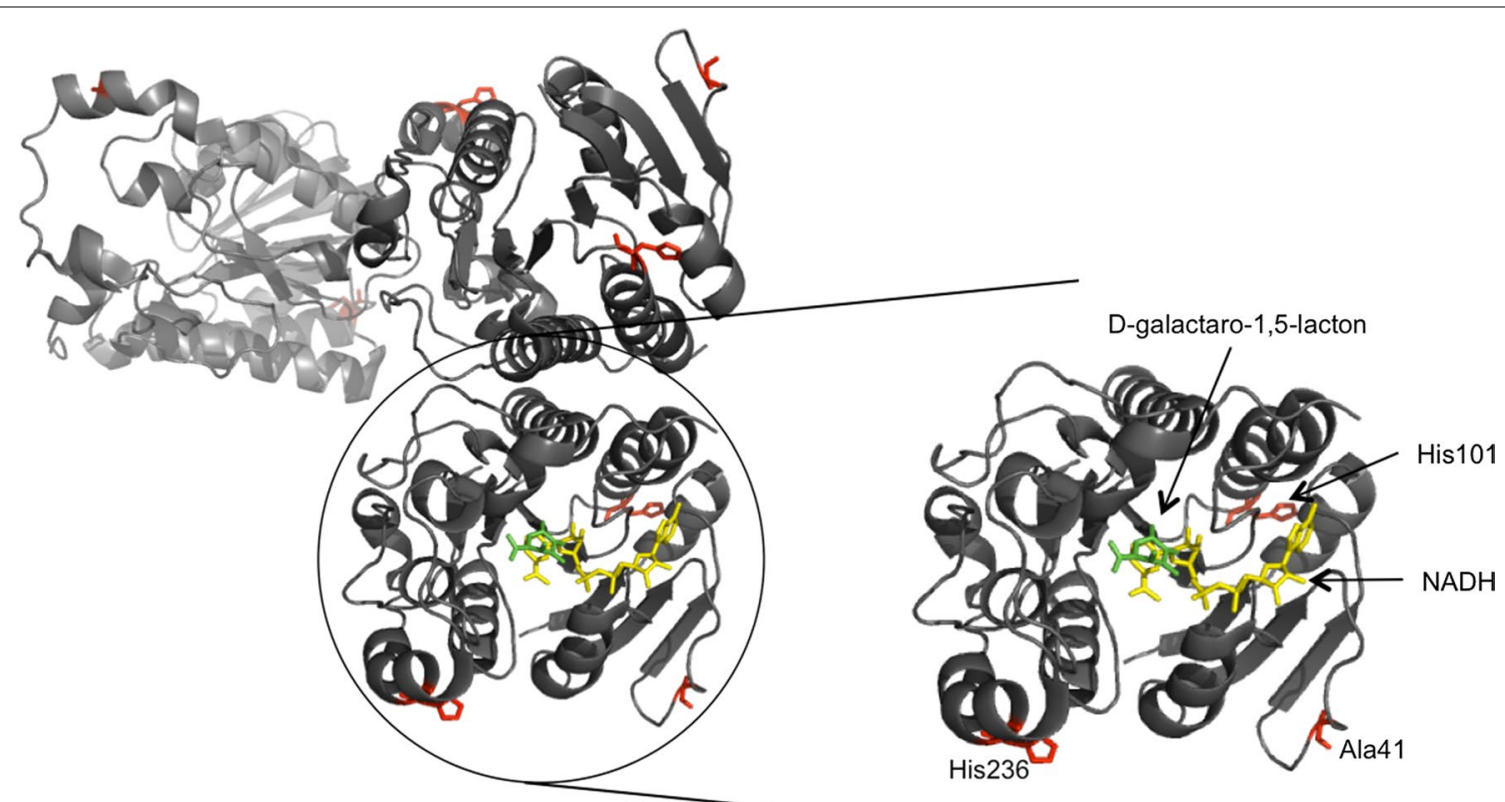

Fig. 4 Three monomers of the UdhAt with a close-up of one highlighted with the mutated amino acids in red, the product D-galactaro-1,5-lactone in green and the cofactor NADH in yellow 
chose WT positions that were not consensus and did not fit a number of structural guidelines and also amino acid positions with a high $B$ factor and replaced them by the consensus amino acid. Thereby they could improve the thermostability of $\alpha$-amino ester hydrolase by $7{ }^{\circ} \mathrm{C}$. This strategy has also the advantage of small libraries and therefore less screening effort. Our strategy of choosing the amino acid positions for mutagenesis was also successful. Furthermore, we found the triple variant A41P/ H101Y/H236K showing better thermostability than WT, which would not be detected by the SGC. It would be interesting to know if both methods-structure guided consensus concept with a low cut-off of $50 \%$ and applying our five criteria-would lead to the same results for thermostabilization when transferred to another Udh. For this purpose the Udh of Chromohalobacter salexigens would be suitable because a crystal structure is already available (Ahn et al. 2012).

In summary, we have shown that the combination of the B factor with knowledge and structure-based criteria is successful for generating thermostable proteins of the UdhAt. The best UdhAt triple variant $(\mathrm{A} 41 \mathrm{P} / \mathrm{H} 101 \mathrm{Y} /$ $\mathrm{H} 236 \mathrm{~K})$ showed an improved $\mathrm{T}_{50}^{15}$ value of $3.2^{\circ} \mathrm{C}$ and a higher thermodynamic stability $\left(\Delta \Delta \mathrm{G}_{\mathrm{U}}=2.3 \mathrm{~kJ} / \mathrm{mol}\right)$. With this approach for improving the stability the UdhAt has been made available for biotechnological applications i.e. for the cell-free production of glucaric or galactaric acid.

\begin{abstract}
Abbreviations
Udh: uronate dehydrogenase; UdhAt: uronate dehydrogenase from Agrobacterium tumefaciens; SDR: short-chain dehydrogenase/reductase; WT: wild type; SGC: structure-guided consensus; E. coli: Escherichia coli; KPi: potassium phosphate; GdmCL: guanidine hydrochloride.
\end{abstract}

\section{Authors' contributions}

All authors read and approval the final manuscript.

\begin{abstract}
Author details
${ }^{1}$ Chair of Chemistry of Biogenic Resources, Straubing Centre of Science, Technical University of Munich, Schulgasse 16, 94315 Straubing, Germany. ${ }^{2}$ Present Address: Roche Diagnostics GmbH, Nonnenwald 2, 82377 Penzberg, Germany. ${ }^{3}$ TUM Catalysis Research Center, Ernst-Otto-Fischer-Straße 1, 85748 Garching, Germany. ${ }^{4}$ Fraunhofer Institute for Interfacial Engineering and Biotechnology IGB, Bio, Electro and Chemocatalysis BioCat, Straubing Branch, Schulgasse 11 a, 94315 Straubing, Germany.
\end{abstract}

\section{Competing interests}

The authors declare that they have no competing interests.

\section{Availability of data and materials}

The data on which the conclusions are made are all presented in this paper.

\section{Ethical statement}

This article does not contain any studies with human participants or animals performed by any of the authors.

\section{Funding}

BB was funded by the Bavarian State Ministry of the Environment and Consumer Protection (Grant Number TGC01GCU-60345). This work was supported by the Technical University of Munich within the funding program Open Access Publishing.

\section{Publisher's Note}

Springer Nature remains neutral with regard to jurisdictional claims in published maps and institutional affiliations.

Received: 14 April 2017 Accepted: 17 May 2017

Published online: 23 May 2017

\section{References}

Ahn J-W, Lee SY, Kim S, Kim SM, Lee SB, Kim K-J (2012) Crystal structure of glucuronic acid dehydrogenase from Chromohalobacter salexigens. Proteins 80(1):314-318

Anbar M, Gul O, Lamed R, Sezerman UO, Bayer E (2012) Improved thermostability of Clostridium thermocellum endoglucanase Cel8A by using consensus-guided mutagenesis. Acad Emerg Med 78(9):3458-3464

Andberg M, Maaheimo H, Boer H, Penttilä M, Koivula A, Richard P (2012) Characterization of a novel Agrobacterium tumefaciens galactarolactone cycloisomerase enzyme for direct conversion of D-galactarolactone to 3-deoxy-2-keto-L-threo-hexarate. J Biol Chem 287(21):17662-17671

Bershtein S, Goldin K, Tawfik DS (2008) Intense neutral drifts yield robust and evolvable consensus proteins. J Mol Biol 379(5):1029-1044

Bloom JD, Arnold FH (2009) In the light of directed evolution: pathways of adaptive protein evolution. Proc Natl Acad Sci USA 106(Suppl):9995-10000

Blum JK, Ricketts MD, Bommarius AS (2012) Improved thermostability of AEH by combining B-FIT analysis and structure-guided consensus method. J Biotechnol 160(3-4):214-221

Boer H, Maaheimo H, Koivula A, Penttilä M, Richard P (2010) Identification in Agrobacterium tumefaciens of the D-galacturonic acid dehydrogenase gene. Appl Microbiol Biotechnol 86(3):901-909

Bommarius AS, Paye MF (2013) Stabilizing biocatalysts. Chem Soc Rev 42(15):6534-6565

Carballeira D, Reetz MT (2007) Iterative saturation mutagenesis (ISM) for rapid directed evolution of functional enzymes. Nat Protoc 2(4):891-903

Gupta RD, Tawfik DS (2008) Directed enzyme evolution via small and effective neutral drift libraries. Nat Methods 5(11):939-942

Guterl J-K, Garbe D, Carsten J, Steffler F, Sommer B, Reiße S, Sieber V (2012) Cell-free metabolic engineering: production of chemicals by minimized reaction cascades. Chemsuschem 5(11):2165-2172

Istomin A, Gromiha M, Vorov O, Jacobs D, Livesay D (2008) New insight into long-range nonadditivity within protein double-mutant cycles. Proteins 70(2):311-319

Jochens H, Aerts D, Bornscheuer UT (2010) Thermostabilization of an esterase by alignment-guided focussed directed evolution. Protein Eng Des Sel 23(12):903-909

Kellis JT, Nyberg K, Fersht R (1989) Energetics of complementary side-chain packing in a protein hydrophobic core. Biochemistry 28(11):4914-4922

Laemmli UK (1970) Cleavage of structural proteins during the assemly of the head of bacteriophage T4. Nature 227:680-685

Lehmann M, Wyss M (2001) Engineering proteins for thermostability: the use of sequence alignments versus rational design and directed evolution. Curr Opin Biotechnol 12(4):371-375

Moon TS, Yoon S, Lanza AM, Roy-Mayhew JD, Prather KL (2009) Production of glucaric acid from a synthetic pathway in recombinant Escherichia coli. Appl Environ Microbiol 75(3):589

Nowak C, Beer B, Pick A, Roth T, Lommes P, Sieber V (2015) A water-forming $\mathrm{NADH}$ oxidase from Lactobacillus pentosus suitable for the regeneration of synthetic biomimetic cofactors. Front Microbiol 6(957):1-9

Parkkinen T, Boer H, Jänis J, Andberg M, Penttilä M, Koivula A, Rouvinen J (2011) Crystal structure of uronate dehydrogenase from Agrobacterium tumefaciens. J Biol Chem 286(31):27294-27300

Parthasarathy S, Murthy MR (2000) Protein thermal stability: insights from atomic displacement parameters (B values). Protein Eng 13(1):9-13

Pick A, Schmid J, Sieber V (2015) Characterization of uronate dehydrogenases catalysing the initial step in an oxidative pathway. Microbiol Biotechnol 8(4):633-643 
Querol E, Perez-Pons J, Mozo-Villarias A (1996) Analysis of protein conformational characteristics related to thermostability. Protein Eng 9(3):265-271 Reetz MT (2013) The importance of additive and non-additive mutational effects in protein engineering. Angew Chem Int Ed 52(10):2658-2666

Reetz MT, Carballeira JD (2006) Iterative saturation mutagenesis on the basis of B factors as a strategy for increasing protein thermostability. Angew Chem Int Ed 45:7745-7751

Reetz MT, Soni P, Acevedo JP, Sanchis J (2009) Creation of an amino acid network of structurally coupled residues in the directed evolution of a thermostable enzyme. Angew Chem Int Ed 48(44):8268-8272

Reizman IMB, Stenger AR, Reisch CR, Gupta A, Connors NC, Prather KLJ (2015) Improvement of glucaric acid production in E. coli via dynamic control of metabolic fluxes. Metab Eng Commun 2:109-116

Skinner MM, Terwilliger TC (1996) Potential use of additivity of mutational effects in simplifying protein engineering. Proc Natl Acad Sci USA 93(20):10753

Smith WS, Hale JR, Neylon C (2011) Applying neutral drift to the directed molecular evolution of a $\beta$-glucuronidase into a $\beta$-galactosidase: two different evolutionary pathways lead to the same variant. BMC Res Notes 4(1):138

Spector S, Wang M, Carp S, Robblee J, Hendsch ZS, Fairman R, Raleigh DP (2000) Rational modification of protein stability by the mutation of charged surface residues. Biochem 39(5):872-879
Sriprapundh D, Vieille C, Zeikus JG (2000) Molecular determinants of xylose isomerase thermal stability and activity: analysis of thermozymes by sitedirected mutagenesis. Protein Eng 13(4):259-265

Studier FW (2005) Protein production by auto-induction in high density shaking cultures. Protein Expr Purif 41(1):207-234

Wagschal K, Jordan DB, Lee CC, Younger A, Braker JD, Chan VJ (2014) Biochemical characterization of uronate dehydrogenases from three Pseudomonads, Chromohalobacter salixigens, and Polaromonas naphthalenivorans. Enzyme Microb Technol 69:62-68

Werpy T, Petersen G (2004) Top value added chemicals from biomass volume I-results of screening for potential candidates from sugars and synthesis gas. Department of Energy, Washington, DC

Wijma HJ, Floor RJ, Janssen DB (2013) Structure- and sequence-analysis inspired engineering of proteins for enhanced thermostability. Curr Opin Struct Biol 23(4):588-594

Yoon S-H, Moon TS, Iranpour P, Lanza AM, Prather KJ (2009) Cloning and characterization of uronate dehydrogenases from two Pseudomonads and Agrobacterium tumefaciens strain C58. J Bacteriol 191(5):1565-1573

You C, Zhang YHP (2012) Cell-free biosystems for biomanufacturing. Adv Biochem Eng Biotechnol 123:127-141

Zajic JE (1959) Hexuronic dehydrogenase of Agrobacterium tumefaciens. J Bacteriol 78(5):734

\section{Submit your manuscript to a SpringerOpen ${ }^{\odot}$ journal and benefit from:}

- Convenient online submission

- Rigorous peer review

- Immediate publication on acceptance

- Open access: articles freely available online

- High visibility within the field

- Retaining the copyright to your article

Submit your next manuscript at springeropen.com 